\title{
Different substrates and protected environments for the initial development of Richeria grandis Vahl seedlings
}

\author{
Cristiane Coelho de Moura ${ }^{1} \oplus$, Thaís Ribeiro Costa ${ }^{1} \oplus$, Paula Alves Oliveira ${ }^{1} \oplus$, Luciana Coelho de Moura ${ }^{2} \oplus$, \\ Letícia Renata de Carvalho $^{3} \odot$, Miranda Titon ${ }^{1} \odot$, Israel Marinho Pereira ${ }^{1} \odot$, Evandro Luiz Mendonça Machado ${ }^{1} \odot$

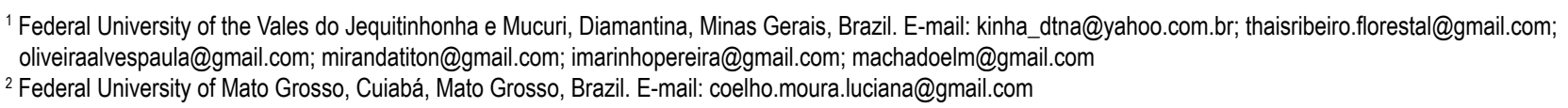

ABSTRACT: Due to the copious anthropization in Gallery Forests and the obligation to restore these spaces, together with the scarcity of information regarding a methodology for seedling emergence and production in a nursery, the objective of this research was to evaluate the impact of different substrates and levels of shading on seedling emergence and quality of the species Richeria grandis Vahl. The fruits, collected in 18 matrix trees in Gallery Forests, were benefited; the seeds were depulped and sown on the same day of collection. The experiment was conducted in a greenhouse, where three substrate compositions were used: $S_{1}-70 \%$ of vermiculite and $30 \%$ carbonized rice husk; $S_{2}-50 \%$ of bioplant ${ }^{\circledR}, 35 \%$ of vermiculite and $15 \%$ carbonized rice husk; $\mathrm{S}_{3}-70 \%$ of subsoil land and $30 \%$ of tanned bovine manure. The substrates were placed in tubes with a capacity of 180 $\mathrm{cm}^{3}$ and maintained under three shading levels: $0 \%, 30 \%$ and $50 \%$. The experimental design was completely randomized in a subdivided block design. All the evaluated characteristics were inferior in the $0 \%$ shading. Emergence, chlorophyll content, height and diameter of the root collar were greater under $30 \%$ and $50 \%$ shading levels, as well as in substrates $\mathrm{S}_{1}$ and $\mathrm{S}_{2}$. The substrate that most positively influenced $R$. grandis seedling quality was the $\mathrm{S}_{2}$. Thus, $R$. grandis is a species that needs shade in the early stage of its development.

Key words: gallery forests; late succession; restoration of degraded areas; seedling production; shading levels

\section{Diferentes substratos e ambientes protegidos para o desenvolvimento inicial de mudas de Richeria grandis Vahl}

RESUMO: Por decorrência do alto grau de antropização em Matas de Galeria e sua obrigatoriedade em restaurá-las, aliada à escassez de informações sobre uma metodologia de emergência e produção de mudas em viveiro, objetivou-se avaliar diferentes substratos e níveis de sombreamentos sobre a emergência e qualidade de mudas da espécie Richeria grandis Vahl. Os frutos, coletados em 18 árvores-matrizes em Matas de Galeria, foram beneficiados, as sementes despolpadas e semeadas no mesmo dia da coleta. 0 experimento foi conduzido em casa de vegetação, onde foram utilizadas três composições de substratos: $\mathrm{S}_{1}-70 \%$ de vermiculita e $30 \%$ de casca de arroz carbonizada; $\mathrm{S}_{2}-50 \%$ de bioplant ${ }^{\oplus}, 35 \%$ de vermiculita e $15 \%$ de casca de arroz carbonizada; $S_{3}-70 \%$ de terra de subsolo e $30 \%$ de esterco bovino curtido. Os substratos foram colocados em tubetes com capacidade de $180 \mathrm{~cm}^{3}$ e mantidos em três níveis de sombreamento: 0,30 e 50\%. 0 delineamento experimental foi 0 inteiramente casualizado em esquema de parcelas sub-subdivididas. Todas as características avaliadas são inferiores no sombreamento $0 \%$. A emergência, o teor de clorofila, a altura e o diâmetro do coleto são maiores nos sombreamentos 30 e $50 \%$, bem como nos substratos $\mathrm{S}_{1}$ e $\mathrm{S}_{2}$. O substrato que mais influenciou, de forma positiva, a qualidade das mudas da $R$. grandis foi o $\mathrm{S}_{2}$. Assim, a $R$. grandis é uma espécie que necessita de sombra na fase inicial de seu desenvolvimento.

Palavras-chave: matas de galeria; sucessão tardia; restauração de áreas degradadas; produção de mudas; níveis de sombreamento 


\section{Introduction}

As a result of copious anthropization in natural ecosystems, the conservation of biodiversity and the restoration of degraded areas are some of the greatest challenges in research today (Gonzaga et al., 2016). Anthropization is effective in many Gallery Forests, which, although protected by Federal Legislation, are classified as Permanent Preservation Area (APP) contained in the New Forest Code (Law no 12651 of 05/25/2012, amended by Law no 12727 of 10/17/2012). Most of these forests have become small isolated fragments with less gene flow, consequently declining populations and plant communities.

There is thus a growing need for the restoration of these areas using ecological and silvicultural knowledge of the species characteristic of this phytocenosis. Studies related to the technique of producing seedlings of native species in these environments are relevant since they increase the perspective of plant survival in the field when compared to the technique of direct seeding (Gonzaga et al., 2016; Klein et al., 2017).

Knowledge about the availability of light (shading) and about the type of substrate for the production of these seedlings is essential, since they play a prominent role in all stages of plant development in the nursery phase. In addition, they are factors that can be manipulated in order to unequivocally contribute to the improvement of the percentage, speed, and uniformity of emergence, providing more homogeneous seedlings, of good quality, fast growth and with good root system formation (Pimentel et al., 2016). Therefore, knowledge of substrates and shading is a critical step in the production of seedlings of any plant species.

In addition, there is no information about the emergence and production of Richeria grandis Vahl. seedlings belonging to the Phyllanthaceae family in the literature. This tree has a natural occurrence, especially in Ciliary and Gallery Forests (Silva, 2017), being an alternative in restoration programs, considering that it is a species compatible with the referenced ecosystem.

Considering the potential use of $R$. grandis, combined with unprecedented information on a methodology for seedling emergence and production in a nursery, this study aimed to evaluate the emergence of this species' seedlings and their initial development in different substrate compositions and shading levels.

\section{Material and Methods}

The experiment was conducted at the Centro Integrado de Propagação de Espécies Florestais (CIPEF), of the Department of Forest Engineering at the Federal University of Vales do Jequitinhonha e Mucuri (UFVJM), Diamantina, Minas Gerais, from February to September 2016, under greenhouse conditions ( $18^{\circ} 12^{\prime} \mathrm{S} ; 43^{\circ} 34^{\prime} \mathrm{W}$, at an altitude of $1370 \mathrm{~m}$ ). The environment was covered with $150 \mu$ thick plastic film, adjusted to four daily irrigations of 10 minutes with a sprinkler system with a flow rate of $10 \mathrm{~L} . \mathrm{h}^{-1}$, and a semi-controlled temperature which averaged $22^{\circ} \mathrm{C}$. Diamantina's climate, according to the Koppen classification, is of the Cwb type, typically subtropical in altitude, characterized by dry winter and mild summer, with annual precipitation ranging from 1250 to $1550 \mathrm{~mm}$, and annual temperature ranging from $16^{\circ} \mathrm{C}$ to $26^{\circ} \mathrm{C}$ (INMET, 2017).

The mature, healthy and inhuman dehiscence fruits of $R$. grandis, collected in February 2016, came from 18 matrix trees selected from three flooded Gallery Forests in Parque Estadual do Biribiri (PEBI), located between 1811'37.5”S and 4334'41.2"W, Diamantina, MG. On the same day of collection, the fruits were transported, in polyethylene packaging, to the CIPEF seed laboratory. The fruits were manually processed, the seeds were depulped (extraction of the sarcotesta by friction over a $0.8 \mathrm{~mm}$ steel mesh sieve), rinsed in running water, disinfested with $1 \%$ sodium hypochlorite for 3 minutes and washed under running water for 10 minutes. Sowing took place on the same day of fruit collection.

Three substrate compositions were used: $S_{1}-70 \%$ of vermiculite and $30 \%$ carbonized rice husk; $\mathrm{S}_{2}-50 \%$ bioplant ${ }^{\circledR}$, $35 \%$ vermiculite and $15 \%$ carbonized rice husk; $\mathrm{S}_{3}-70 \%$ subsoil and $30 \%$ tanned manure. These compositions were submitted to fertility analysis in the substrate characterization laboratory of the Department of Forest Engineering of UFVJM and interpreted according to Ribeiro et al. (1999). After the analysis, controlled-release fertilizer (Osmocote ${ }^{\circledR}$ ) was added in the proportion of 15:9:12 (NPK) and with a substrate concentration of $5 \mathrm{~g} \mathrm{~L}^{-1}$, with slow release from 5 to 6 months, following the manufacturer's recommendation for the development of native seedlings.

The substrates were placed in rigid polyethylene tubes with a capacity of $180 \mathrm{~cm}^{3}$ with an open bottom for draining excess water, and were maintained under three different levels of shading: $0 \%, 30 \%$ and $50 \%$. Artificial shading was obtained by placing the plants under natural radiation conditions inside the greenhouse $(0 \%)$ and under cover with a commercial black polyethylene shading screen (sombrite) with $30 \%$ and $50 \%$ attenuation of solar radiation.

During the sowing, two seeds were used per tube, in order to maintain only the most vigorous seedling after thinning, with a standardization of $1 \mathrm{~cm}$ deep, covered with substrates so that they were not visible. To perform the emergence test, the number of emerged seedlings was recorded daily at the same time from the 1st to the 40th day, after the installation of the experiment. Thinning was performed after 40 days of evaluations. The performance of seedling emergence was based on the percentage of emergence (\%), emergence speed index (IVE) and mean emergence time (TME). The IVE was calculated according to the formula presented by Maguire (1962) and the TME, according to Labouriau (1983).

To evaluate the development of seedlings, height $(H)$ was measured in $\mathrm{cm}$ (from the base of the seedling to the apical bud), as well as the diameter of the root collar (DAC) (mm) and total chlorophyll (Falker chlorophyll index) at 90, 120, 150 and 180 days after sowing.

The diameter was measured with the aid of a graduated 
caliper (accuracy of $0.01 \mathrm{~mm}$ ); the height, with a millimeter ruler with the zero positioned at the base of the plant; and the total chlorophyll, based on readings from at least two leaves per individual, taken in a non-destructive way, using the chlorophyll meter, individually measured by the portable meter ClorofiLOG1030 ${ }^{\circledR}$.

After 210 days, the percentage of mortality (\%) was evaluated counting, and $50 \%$ of the live seedlings of each treatment were selected for the quantification of shoot and root dry biomass. The roots were separated from the substrate by washing under running water. The root and shoot material were separated at the seedling neck, and both parts were placed separately in properly identified kraft paper bags, dried in an oven at $80^{\circ} \mathrm{C}$ and weighed on a precision scale (0.001 g) periodically.

The action of the substrates associated with the different shading intensities on the performance of the seedlings was evaluated by quantifying the shoot dry mass (g) (MSPA) and root dry mass (g) (MSR) and, from such values, the total dry mass (g) (MST) and the MSPA/MSR ratio were determined. In addition, the ratios between height $(\mathrm{cm})$ and diameter $(\mathrm{cm})$ (H/D) and H/MSPA were calculated. Based on the data, the quality of seedlings was assessed using the Dickson quality index (IQD) (Dickson et al., 1960).

The experimental design used for the analysis of emergence (40 days), mortality and seedling quality (210 days), was completely randomized in a split-plot design (3 $x$ 3), in which the main plots contemplated shading and the subplots, substrates. For the evaluations at different times, the experimental design remained completely randomized, however in a subdivided block design ( $3 \times 3 \times 5)$, in which the main plots contemplated shading; the subplots, substrates; and the sub-subplots, the five different times. The experimental unit consisted of five seedlings, with six replicates per treatment, totaling 270 seedlings.

The data were subjected to statistical assumption tests. The data referring to the emergence, mortality, and quality of seedlings, were submitted to the $F$ test for analysis of variance at a $5 \%$ significance level, with the means being compared by the Tukey test with a $5 \%$ probability of error. The data obtained under different times were subjected to the $\mathrm{F}$ test for analysis of variance at a $5 \%$ significance level and, giving significant interaction $(p<0.05)$ with time, regression analyses and model identity testing were performed. The free statistical software R-3.3.3 (2017) was used for all analyses, as well as the additional packages "ExpDes" (Experimental Designs) (Ferreira et al., 2013) and "agricolae" (Mendiburu, 2016).

\section{Results and Discussion}

The $\mathrm{pH}$ in water of the $\mathrm{S}_{1}$ and $\mathrm{S}_{3}$ substrates was shown to be high and very high respectively (Table 1 ), while $S_{2}$ was reported as adequate according to Ribeiro et al. (1999). Most of the values of the chemical and physical-chemical variables analyzed, with the exception of potential acidity, were significantly higher in compositions that received commercial
Table 1. Chemical, physico-chemical characteristics of $S_{1}, S_{2}$ and $\mathrm{S}_{3}$ substrates and particle size characteristic of substrate 3 for the emergence and initial development of Richeria grandis Vahl. (Phyllanthaceae) in a greenhouse.

\begin{tabular}{|c|c|c|c|c|c|c|}
\hline \multirow{2}{*}{$\begin{array}{l}\text { Identification } \\
\mathrm{pH} \text { (water) }\end{array}$} & \multicolumn{2}{|c|}{ Substrate $\mathrm{S}_{1}$} & \multicolumn{2}{|c|}{ Substrate $S_{2}$} & \multicolumn{2}{|c|}{ Substrate $S_{3}$} \\
\hline & 6.2 & $A$ & 5.9 & $\mathrm{Bm}$ & 7.1 & MA \\
\hline$P\left(\mathrm{mg} \mathrm{dm}^{-3}\right)$ & 432 & $\mathrm{MBm}$ & 432 & $\mathrm{MBm}$ & 266 & $\mathrm{MBm}$ \\
\hline $\mathrm{K}\left(\mathrm{mg} \mathrm{dm} \mathrm{m}^{-3}\right)$ & 323 & $\mathrm{MBm}$ & 357 & $\mathrm{MBm}$ & 707 & $\mathrm{MBm}$ \\
\hline $\mathrm{Ca}\left(\mathrm{cmolc} \mathrm{dm}^{-3}\right)$ & 0.7 & B & 7.1 & $\mathrm{MBm}$ & 5.6 & $\mathrm{MBm}$ \\
\hline $\mathrm{Mg}\left(\mathrm{cmolc} \mathrm{dm}^{-3}\right)$ & 0.2 & B & 2.1 & $\mathrm{MBm}$ & 1.8 & $\mathrm{MBm}$ \\
\hline 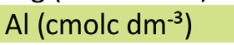 & 0.06 & $\mathrm{MB}$ & 0.08 & $\mathrm{MB}$ & 0.02 & MB \\
\hline 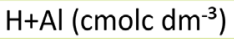 & 1.0 & MB & 4.7 & $\mathrm{M}$ & 1.0 & $\mathrm{MB}$ \\
\hline $\mathrm{SB}\left(\mathrm{cmolc} \mathrm{dm}^{-3}\right)$ & 1.7 & B & 10.2 & $\mathrm{MBm}$ & 9.1 & $\mathrm{MBm}$ \\
\hline $\mathrm{t}\left(\mathrm{cmolc} \mathrm{dm}^{-3}\right)$ & 1.8 & B & 10.2 & $\mathrm{MA}$ & 9.2 & $\mathrm{MA}$ \\
\hline $\mathrm{T}\left(\mathrm{cmolc} \mathrm{dm}^{-3}\right)$ & 2.7 & $M$ & 14.9 & A & 10.1 & A \\
\hline m (\%) & 3.4 & $\mathrm{MB}$ & 0.8 & $\mathrm{MB}$ & 0.2 & $\mathrm{MB}$ \\
\hline$V(\%)$ & 63 & A & 68 & A & 90 & MA \\
\hline M.O. $\left(\right.$ dag kg $\left.^{-1}\right)$ & 0.0 & $\mathrm{MB}$ & 5.0 & $\mathrm{Bm}$ & 3.8 & M \\
\hline \multicolumn{7}{|c|}{ Granulometric analysis of the soil } \\
\hline Sand (dag $\mathrm{kg}^{-1}$ ) & - & & - & & 79 & \\
\hline Silt (dag kg-1) & - & & - & & 15 & \\
\hline Clay $($ dag kg-1) & - & & - & & 6 & \\
\hline
\end{tabular}

Water $\mathrm{pH}$ : 1: 2.5 soil-water ratio. $\mathrm{P}$ and $\mathrm{K}$ : Mehlich-1 extractor. $\mathrm{Ca}, \mathrm{Mg}$ and $\mathrm{Al}: \mathrm{KCl}$ Extractor $1 \mathrm{~mol} \mathrm{~L}^{-1}$. t: Effective cation exchange capacity. T: Cation exchange capacity at $\mathrm{pH}$ 7.0. $\mathrm{m}$ : Saturation of aluminum. V: Base saturation. MO: Organic matter determined by the Walkey-Black method. Where: MB - Very low, B - Low, M - Medium, Bm - Good, $\mathrm{MBm}$ - Very good, A - High and MA - Very high.

substrate Bioplant ${ }^{\circledR}\left(\mathrm{S}_{2}\right)$ and tanned bovine manure-type organic compound $\left(\mathrm{S}_{3}\right)$, indicating an increase in fertility, due to increased levels of $\mathrm{P}, \mathrm{Ca}, \mathrm{Mg}$ and also the sum of bases, effective $\mathrm{CTC}$ and in neutral $\mathrm{pH}$ and organic matter.

The chemical analysis of the substrates allows to infer that there is a great availability of nutrients, mainly in the substrate $\mathrm{S}_{2}$, especially phosphorus (Table 1 ), where its limitation can result in restrictions on growth, especially during the initial phases (Gonçalves et al., 2013), since it is an integral component of important plant cell compounds, including phosphate-sugars, respiration and photosynthesis intermediates, as well as the phospholipids that make up plant membranes (Taiz \& Zeiger, 2013). Despite this, it is worth mentioning that a dosage of $5 \mathrm{~g} \mathrm{~L}^{-1}$ of the NPK fertilizer was added in all analyzed substrates, and no symptoms such as chlorosis and/or leaf necrosis were observed, which could evidence some type of phytotoxicity (Kratka \& Correia, 2015) in any of the compositions simultaneously.

The $S_{1}$ and $S_{2}$ substrates provided a higher percentage of emergence and IVE (Table 2). 30\% shading increased IVE, while the absence of shading $(0 \%)$ had a negative influence on IVE (Table 2), when compared to other treatments.

The results of the $R$. grandis TME averages of the shading factor within the $\mathrm{S}_{1}$ and $\mathrm{S}_{2}$, according to the $\mathrm{F}$ test, are statistically equal, presenting averages around 20 days. The 30\% (19.7 days) and 50\% (18.2 days) shading treatment resulted in lower TME when compared to $0 \%$ shading $(27.3$ days) inside the substrate $S_{3}$. Regarding the substrate factor within the $0 \%$ shading, it is observed that the substrates $S_{1}$ (21.1 days) and $\mathrm{S}_{2}$ (20.0 days) exhibit lower TME than $\mathrm{S}_{3}$ (27,3 days). The substrate factor within the $30 \%$ and $50 \%$ shading 
Table 2. Emergence (\%) and emergence speed index (IVE) of Richeria grandis Vahl seedlings. (Phyllanthaceae) submitted to three types of shading and three substrate compositions in a greenhouse.

\begin{tabular}{ccc}
\hline Substrate & Emergence (\%) & IVE \\
\hline $\mathrm{S}_{1}$ & $99 \mathrm{a}$ & $3.64 \mathrm{a}$ \\
$\mathrm{S}_{2}$ & $98 \mathrm{a}$ & $3.35 \mathrm{a}$ \\
$\mathrm{S}_{3}$ & $83 \mathrm{~b}$ & $2.77 \mathrm{~b}$ \\
\hline Shading & & \\
\hline Without sombrite (0\%) & $86^{\mathrm{ns}}$ & $2.86 \mathrm{~b}$ \\
Sombrite 30\% & $100^{\mathrm{ns}}$ & $3.85 \mathrm{a}$ \\
Sombrite 50\% & $94^{\mathrm{ns}}$ & $3.36 \mathrm{ab}$ \\
\hline
\end{tabular}

Where: ${ }^{\text {ns }}$ not significant at $5 \%$ probability of error. Averages followed by the same letter do not differ by Tukey's test at $5 \%$ probability of error.

are statistically equal, with averages around 20 days. In short, the composition of the substrate $\mathrm{S}_{3}$ and $0 \%$ shading are responsible for causing a greater TME for $R$. grandis.

According to Gonçalves et al. (2013), substrates with greater porosity, but with moisture retention capacity preventing the rapid loss of water, can favor the emergence of seedlings. Araújo \& Paiva Sobrinho (2011) also found that the IVE, the greatest growth of seedlings and the greatest expression of vigor, was provided by the presence of carbonized rice husks and vermiculite in the formation of their substrates.

The IVE allows inferring the efficiency of germination and seedling emergence (Gonçalves et al., 2013), since the shorter the time of exposure of the seeds to adverse factors, which may cause some type of damage in terms of production, the greater the probability of that the seedling has more development.

For the dependent interaction between shading and substrate, both qualitative, there was a greater height of the seedlings in the substrates $\mathrm{S}_{1}$ and $\mathrm{S}_{2}$ within all types of shading tested. $30 \%$ and $50 \%$ shading provided greater height of the seedlings within the substrates $\mathrm{S}_{2}$ and $\mathrm{S}_{3}$. All shadows within the $S_{1}$ substrate are statistically equal (Table 3 ).

When relating the influence of the types of shading tested on the growth in height over time, it is noted that the height was greater for $30 \%$ and $50 \%$ shading, represented by quadratic equations (Figure $1 \mathrm{~A}$ ). The mortality of some seedlings in the sample units, which provided the highest average within the plot with no solar attenuation (0\%), justifies the decrease in averages over 120 days to 150 days, in the absence of shading. The substrates $\mathrm{S}_{1}$ and $\mathrm{S}_{2}$ similarly

Table 3. Average height $(\mathrm{H})(\mathrm{cm})$ of Richeria grandis Vahl seedlings (Phyllantahaceae) submitted to three types of shading and three substrate compositions in a greenhouse.

\begin{tabular}{cccc}
\hline \multirow{2}{*}{ Shading } & \multicolumn{3}{c}{$\mathbf{H}(\mathbf{c m})$} \\
\cline { 2 - 4 } & Substrate 1 & Substrate 2 & Substrate 3 \\
\hline Without sombrite (0\%) & $6.80^{\mathrm{ns} a}$ & $5.97 \mathrm{Ba}$ & $3.83 \mathrm{Bb}$ \\
Sombrite 30\% & $7.68^{\mathrm{ns} a}$ & $7.47 \mathrm{Aa}$ & $5.72 \mathrm{Ab}$ \\
Sombrite 50\% & $7.33^{\mathrm{ns} a}$ & $7.10 \mathrm{Aa}$ & $5.06 \mathrm{Ab}$ \\
\hline
\end{tabular}

Where: uppercase letters compare different shading (lines) for the same substrate (columns) and lowercase letters compare different substrates (columns) for the same shading (lines) (Tukey's test) at $5 \%$ probability of error. ${ }^{\text {ns }}$ Not significant at $5 \%$ probability of error.
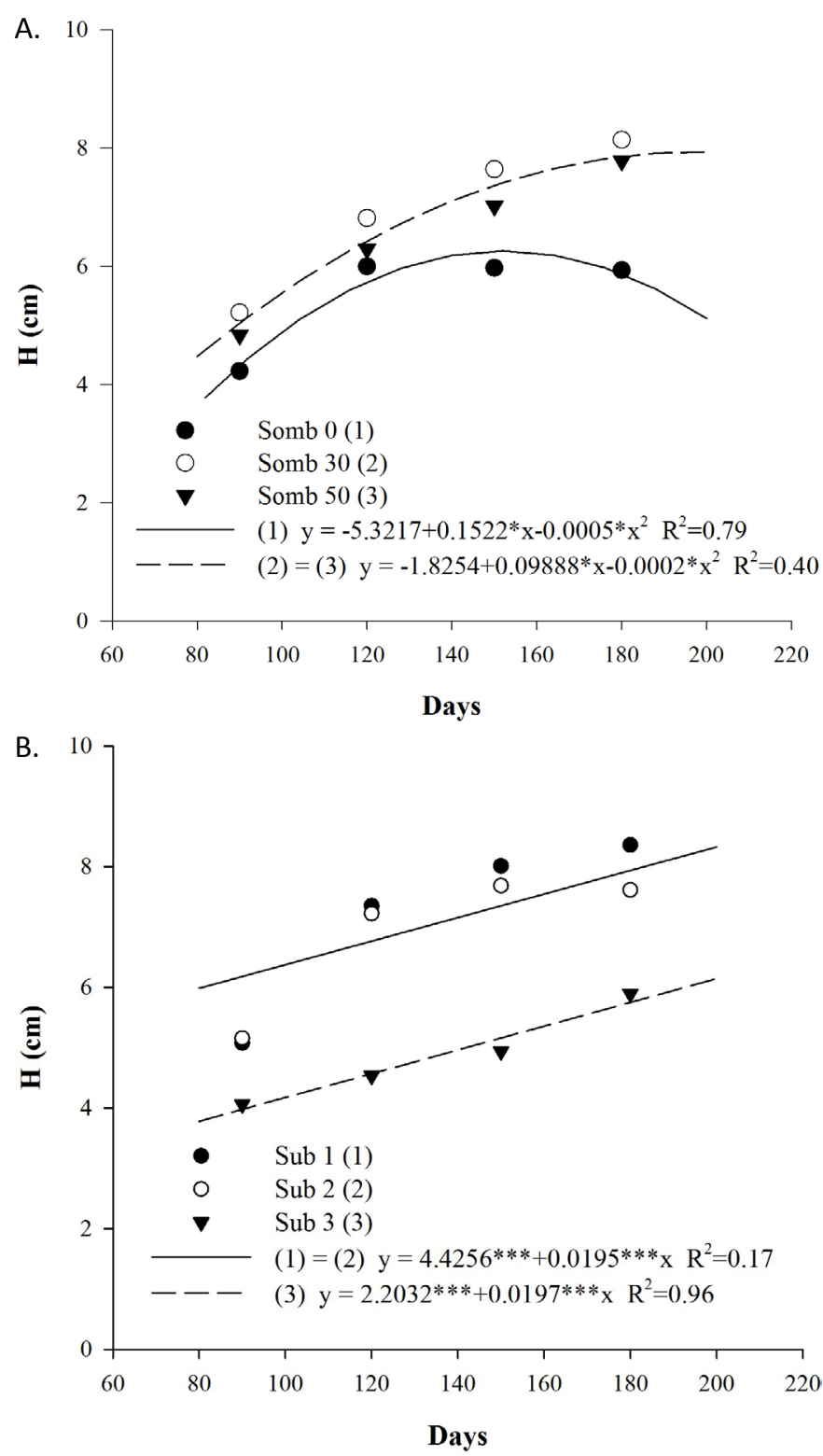

Figure 1. Relationship between the time elapsed from the first to the last evaluation (90,120, 150 and 190 days) after emergence and the height $(\mathrm{H})(\mathrm{cm})$ of Richeria grandis Vahl seedlings, submitted to different levels of shading $(A)$ and substrate compositions (B), in a greenhouse.

promoted the greatest linear growth of $R$. grandis seedlings over time, compared to substrate $S_{3}$ (Figure 1B).

Like the Copaifera langsdorffii Desf. researched by Reis et al. (2016) and Calophyllum brasiliensis Cambess (Nery et al., 2016), species tolerant to shade and more advanced stages of succession, $R$. grandis grows more in height in environments with intermediate brightness (30\% and $50 \%$ ), such as glades. This result in environments with low light, provided by the presence of physical protectors, is usually more intense (Klein et al., 2017), given that the elongation of the stem characterizes a response to the action of phytochrome in the perception of light beams (Taiz \& Zeiger, 2013), causing the seedling to fade due to adaptive mechanisms to enable greater growth in environments with restricted light (Gomes 
Júnior et al., 2017).

The largest root collar diameters for $R$. grandis were observed in the treatments that contained the substrates $S_{1}$ or $S_{2}$, both equal by the Tukey test $(p<0.05)$, with averages of 20.5 and $21.4 \mathrm{~mm}$ respectively. Smaller diameters were obtained in the seedlings that were contained in the substrate $\mathrm{S}_{3}(18.2 \mathrm{~mm}) .30 \%$ and $50 \%$ shading can be represented by only one linear equation increasing over time, according to the model identity test, they were also able to provide a better performance in diameter growth for $R$. grandis seedlings (Figure 2).

Shading, substrate and time factors depend on the amount of total chlorophyll present in the leaves of $R$. grandis seedlings. All regressions were significant at a $1 \%$ probability of error, except for the treatment represented by $50 \%$ shading in the plot and $S_{1}$ substrate in the subplot (Somb 50 - Sub 1).

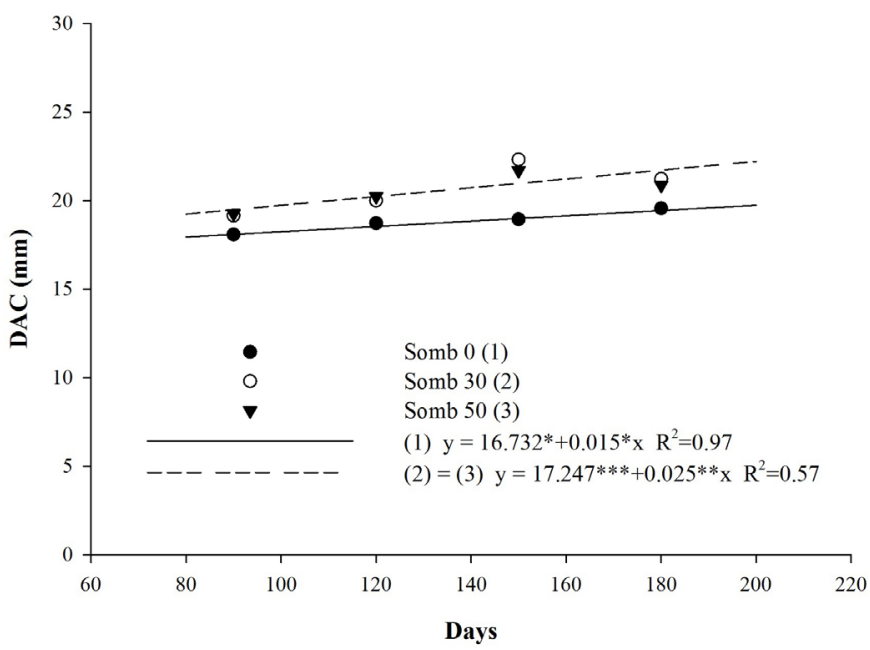

Figure 2. Relationship between the time elapsed from the first to the last evaluation (90,120, 150 and 190 days) after emergence, and the diameter of the root collar (DAC) $(\mathrm{mm})$ submitted to different levels of shading, in a greenhouse.
Even so, the midpoints of each time for this treatment are plotted on the graph (Figure 3).

The model identity test indicated that the treatments $0 \%$ shading in the plot and substrate $S_{1}$ in the subplot (Somb 0 Sub 1), Somb 0 - Sub 2, Somb 30 - Sub 1, Somb 30 - Sub 2 and Somb 50 - Sub 2, provided the highest amounts of chlorophyll, compared to the other treatments, being represented by a single quadratic equation, thus observing an increase in the amount of total chlorophyll up to 150 days and a decrease in the Falker chlorophyll index from of this time (Figure 3). It should be noted that the midpoints of these five treatments (Figure 3) come from the data from all observations, and the higher concentration of data, with a lower amount of chlorophyll, shifted the averages below the trend line.

The same trend is observed for the Somb 30 - Sub 3 treatment, but with a lower average amount of chlorophyll (Figure 3). As for the $\mathrm{S}_{3}$ substrate used in the shaded plots with $0 \%$ and $50 \%$, the results were explained by linear regressions increasing over time, with the treatment Somb 0 - Sub 3 with higher means of chlorophyll over time, compared to Somb 50 - Sub 3 (Figure 3).

Regarding the amount of total chlorophyll, the results for the formation of $R$. grandis seedlings did not show a clear and consistent pattern in relation to the best shading, since the model identity test indicated the highest means of total chlorophyll, represented by a single equation, found in all tested shading levels (0\%, 30\% and 50\%). However, studying R. grandis seedlings, Oliveira (2014) states that 30\% and $70 \%$ shading generated higher levels of total chlorophyll, while the treatment in full sun caused the lowest values.

When researching Brazil nuts, Albuquerque et al. (2015) also found no significant differences for the average levels of total chlorophyll submitted to different levels of shading, inferring that it can be an adaptive strategy, thus corroborating the results of this study. Higher levels of total chlorophyll were also observed for $C$. brasiliensis at different levels of shading,

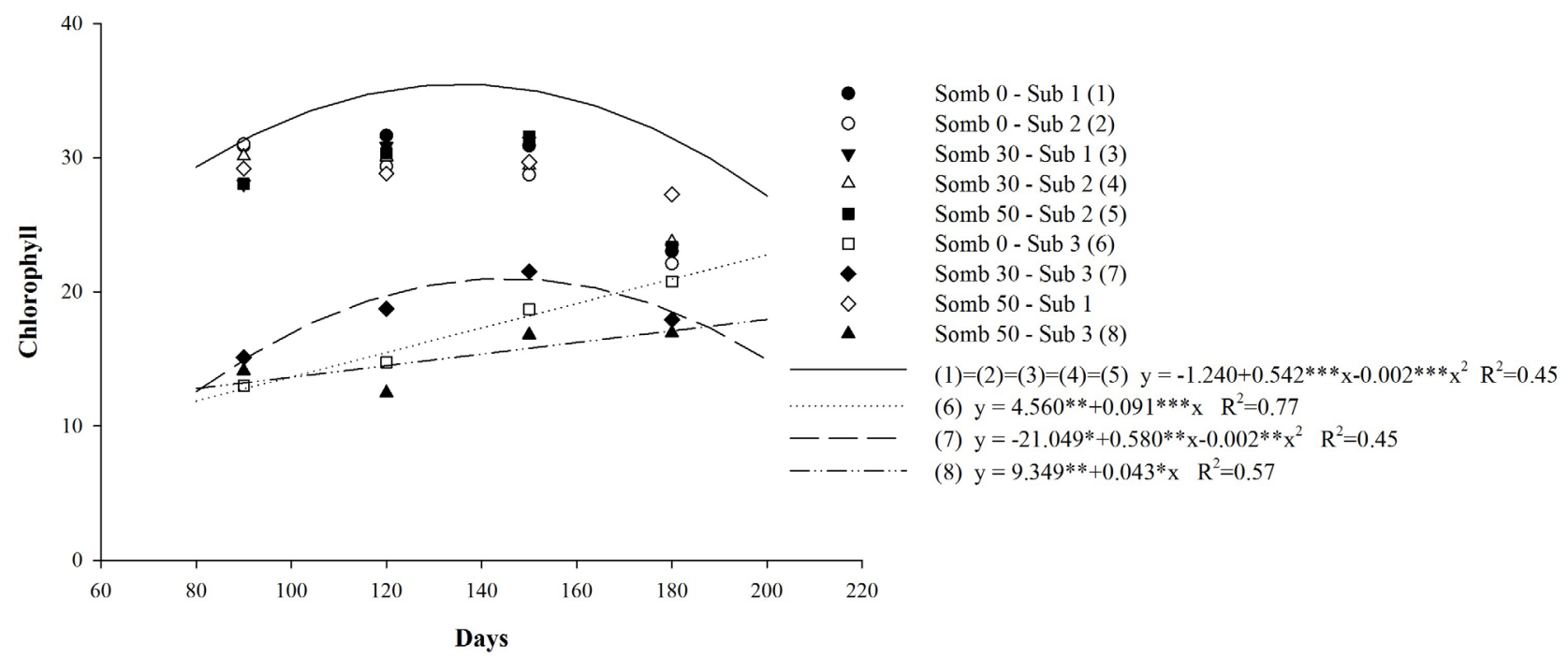

Figure 3. Relationship between the time elapsed from the first to the last evaluation (90, 120, 150 and 190 days) after emergence and the amount of average total chlorophyll (Chlorophyll Falker Index) of Richeria grandis Vahl seedlings, under the effect of combinations of three levels of shading and three substrate compositions, in a greenhouse. 
as reported by Nery et al. (2016), with higher averages in leaves submitted to full sun, at $30 \%$ and $70 \%$ shading.

Thus, it is only observed that the substrates $S_{1}$ and $S_{2}$ influenced the performance of the seedlings by stimulating the production of chlorophyll, when compared to the treatments that contained the substrate $\mathrm{S}_{3}$ (Figure 3). Although the regression for the substrate $S_{1} 50 \%$ shading was not significant, average levels of total chlorophyll are observed, similar to the best means of chlorophyll in response to treatments containing the substrate $S_{1}$ and $S_{2}$ at any level of shading (Figure 3).

At 210 days, $R$. grandis seedlings had a significant mortality ( $p<0.05$ ) involving the shading and substrate factors, with emphasis on the difference between those inserted in the parcel without shade $(0 \%)(p<0.05)$ and those under $30 \%$ and $50 \%$ shading (Table 4 ). The average percentage of mortality was also higher for $R$. grandis seedlings produced in $\mathrm{S}_{3^{\prime}}$, differing $(p<0.05)$ from those sown in substrates $S_{1}$ and $S_{2^{\prime}}$, which are considered equal (Table 4).

Due to the total mortality (100\%) of the seedlings submitted to $0 \%$ shading in the plot, and to the substrate $\mathrm{S}_{3}$ in the subplot, at 210 days, this subplot was removed from all plots for the preceding analyzes.

When evaluating the MSPA values of $R$. grandis seedlings, it can be observed that the substrates $S_{1}$ and $S_{2}$, with equal values ( $p>0.05)$, stood out when subjected to $50 \%$ shading, differing $(p<0.05$ ) to the portion subjected to $0 \%$ shading (Table 4). The same answer was found for the mean MST values of $R$. grandis seedlings. Regarding the MSR and the MSPA/MSR ratio, all data are equal to a $5 \%$ error probability, both for the different substrates tested and for the three types of shading (Table 4).

In the same way that Copaifera (Reis et al., 2016) obtained higher MSPA in intermediate shading conditions, with the use of $30 \%$ and $50 \%$ shading, this behavior was also observed for $R$. grandis. It obtained an increase in the photosynthetic area resulting in greater efficiency in the production of photoassimilates (Taiz \& Zeiger, 2013), being able to cause greater growth in height, diameter, and biomass of the shoot. It should also be noted that Albuquerque et al. (2015), studying the formation of seedlings of Castanheira do Brasil, observed plants of greater height, with a greater number of leaves, and consequently greater MSPA, certifying the results found for $R$. grandis.

Regarding the MST, Lima et al. (2010) also observed a decrease in the production of biomass in plants grown under no shading. In addition, the ambient temperature in conditions of greater shading can be much lower, leading to a greater availability of humidity in the environment and, consequently, to a lower rate of transpiration of the leaves, reducing the possible stress for the seedlings and using their energy for the production of biomass.

The substrate that most positively influenced the quality of $R$. grandis seedlings was $\mathrm{S}_{2}$ (Table 4). Meanwhile, the shading treatments of $30 \%$ and $50 \%$ of attenuation of solar radiation influenced in a similar way. The seedlings, belonging to the plots that correspond to the absence of shading in the greenhouse, produced lower IQD $(p<0.05)$ when compared to other shading (Table 4).

A similar result was found by Gonçalves et al. (2013), with emphasis on the organic compost and vermiculite treatments, also observed in the present study, since $S_{1}$ provided a higher quality of seedlings at 210 days. This is probably related to the fact that the presence of organic compounds in the substrate commercial Bioplant ${ }^{\circledR}$ make nutrients more easily available to seedlings, and the vermiculite has better structure and moisture retention, characteristics that, according to these authors, stimulate the growth and quality of seedlings.

Pimentel et al. (2016) also state that the production of quality seedlings is achieved by mixing some type of organic substrate with mineral substrates. In this sense, the results of this research for the IQD showed that plants that are grown in vermiculite, commercial substrate Bioplant ${ }^{\circledR}$ and carbonized rice husk $\left(\mathrm{S}_{2}\right.$ substrate) subjected to 30 and $50 \%$ shading provided the highest averages, which classifies it as better quality. This classification is justified by the robustness and balance of the seedling biomass distribution, which includes the morphological parameters associated with seedling survival and quality, as reported by Bonamigo et al. (2016).

Discocarpus pedicellatus Fiaschi e Cordeiro, which belongs to the same family of the species under study (Phyllanthaceae), endemic to Brazil and occurring in rainforests, studied by Mercês et al. (2013), has characteristics of a late succession tree species, in view of the great ability to tolerate and develop

Table 4. Mortality percentage (\%), shoot dry mass (MSPA) (g), root dry mass (MSR) (g), total dry mass (MST) (g), MSPA/MSR ratio and Dickson's quality index (IQD) of Richeria grandis Vahl seedlings. (Phyllanthaceae) subjected to three types of shading and two substrate compositions at 210 days, in a greenhouse.

\begin{tabular}{|c|c|c|c|c|c|c|}
\hline \multirow{2}{*}{ Substrate } & \multirow{2}{*}{$\begin{array}{c}\text { Mortality } \\
(\%)\end{array}$} & MSPA & MSR & MST & MSPA/MSR & IQD \\
\hline & & \multicolumn{5}{|c|}{ (g) } \\
\hline 1 & $12.2 \mathrm{a}$ & $4.4^{\mathrm{ns}}$ & $5.4^{\mathrm{ns}}$ & $9.8^{\mathrm{ns}}$ & $0.84^{\mathrm{ns}}$ & $2.3 \mathrm{~b}$ \\
\hline 2 & $20 a$ & $4.5^{\mathrm{ns}}$ & $5.5^{\mathrm{ns}}$ & $10.0^{\mathrm{ns}}$ & $0.82^{n s}$ & $2.7 \mathrm{a}$ \\
\hline 3 & $77.8 \mathrm{~b}$ & - & - & - & - & - \\
\hline \multicolumn{7}{|l|}{ Shading } \\
\hline Without sombrite $(0 \%)$ & $51.1 \mathrm{~b}$ & $4.2 \mathrm{~b}$ & $4.9^{\mathrm{ns}}$ & $9.0 \mathrm{~b}$ & $0.87^{\mathrm{ns}}$ & $1.7 \mathrm{~b}$ \\
\hline
\end{tabular}

Where: ${ }^{\text {ns }}$ not significant at 5\% probability of error. Averages followed by the same letter do not differ by Tukey's test at $5 \%$ probability of error. 
under high levels of shading (50\%) through adjustments in primary metabolism. In this way, $R$. grandis can also be classified as a late-successional species, since it evidences the best significant development since emergence, its seedling quality development at 210 days under evaluation in shaded places (30\% and $50 \%$ shading), and mortality in places without shading, also confirmed by studies by Oliveira (2014).

The natural occurrence of $R$. grandis is more frequent in the interior of Gallery Forests, often composing the canopy of these woods, close to the watercourse (Silva et al., 2016), confirming its adaptability to intermediate light conditions. Thus, $R$. grandis seedlings introduced in areas simulating a glade reveal aspects indicative of possible success in their establishments. Their cultivation is not recommended in areas where there is total suppression of tree vegetation, such as areas in full sun. The substrate $S_{3}$ presented itself as the least viable for the production of $R$. grandis seedlings, although the subsoil is one of the most used components for the production of forest seedlings in nurseries (Davide et al., 2015). Because of availability and reduced prices (Pimentel et al., 2016), and tanned bovine manure, a substrate component proven by Kratka \& Correia (2015), with a higher content of organic matter, offered similar results in diameter, number of leaves and seedling quality index in comparison to other types of organic compounds.

A factor that may have affected $\mathrm{S}_{3}$ the other compositions of substrates studied is the non-conference of the biological stability of tanned bovine manure, which could not be well decomposed. According to Davide et al. (2015), badly decomposed organic materials still have a high activity of microorganisms, which can compete with the seedlings mainly for the nitrogen present in the substrate. Also, the poor decomposition of manure combined with alkaline $\mathrm{pH}$ favors the existence and abundance of bacteria (Taiz \& Zeiger, 2013), causing nitrogen deficiency for the seedlings, impairing the formation of chlorophyll (Figure 2) and inhibiting their growth (Bonamigo et al., 2016).

Another aspect that may have negatively influenced the results for $R$. grandis in the composition of the substrate $\mathrm{S}_{3}$, is the low percentage of clay in its structure (6\%) combined with standard irrigation for all tested compositions, since the presence of clay is considered very important due to its proven efficiency in water retention as it has a smaller diameter $(<0.002 \mathrm{~mm})$ and high specific surface area (Costa et al., 2016).

Therefore, for the initial development of vigorous $R$. grandis seedlings, in addition to a substrate that provides an adequate structure and consistency (Davide et al., 2015), high capacity for aeration, drainage and water retention, as well as freedom from competing microorganisms, the species must be under a condition of adequate shading for its development, avoiding excessive stress and later death.

\section{Conclusion}

The composition of the substrates $\mathrm{S}_{1}(70 \%$ vermiculite and $30 \%$ carbonized rice husk) and $\mathrm{S}_{2}$ (50\% bioplant ${ }^{\circledR}$, $35 \%$ vermiculite and $15 \%$ carbonized rice husk) favors the emergence of seedlings and increases the chlorophyll content in $R$. grandis leaves.

The substrates $\mathrm{S}_{1}$ and $\mathrm{S}_{2}$ and the shading levels of $30 \%$ and $50 \%$ promote increased vigor, height and diameter of the root collar.

For better quality seedlings, it is recommended to cultivate $R$. grandis on substrates composed of commercial substrate Bioplant ${ }^{\circledR}$, vermiculite and carbonized rice husk, in the proportion $50 \%, 35 \%$ and $15 \%$ respectively, under shading of $30 \%$ or $50 \%$.

$R$. grandis is a species that needs shade during the initial stage of its development. Shading levels of $30 \%$ and $50 \%$ are a viable alternative for the production of seedlings of the species.

\section{Acknowledgements}

The present study was carried out with the support of the Coordination for the Improvement of Higher Education Personnel - Brazil (CAPES) - Financing Code 001, and the company Anglo American Brazil.

\section{Literature Cited}

Albuquerque, T.C.S.; Evangelista, T.C.; Albuquerque Neto, A.A.R. Níveis de sombreamento no crescimento de mudas de castanheira do Brasil. Revista Agro@mbiente Online, v.9, n.4, p.440-445, 2015. https://doi.org/10.18227/1982-8470ragro.v9i4.3025.

Araújo, A.P.; Paiva Sobrinho, S. Germinação e produção de mudas de tamboril (Enterolobium contortisiliquum (Vell.) Morong em diferentes substratos. Revista Árvore, v.35, n.3, p.581-588, 2011. https://doi.org/10.1590/S0100-67622011000400001.

Bonamigo, T.; Scalon, S.P.Q.; Pereira, Z.V. Substratos e níveis de luminosidade no crescimento inicial de mudas de Tocoyena formosa (Cham. \& Schltdl.) K. Schum. (RUBIACEAE). Ciência Florestal, v.26, n.2, p. 501-511, 2016. https://doi. org/10.5902/1980509822750.

Costa, C.D.O.; Alves, M.C.; Sousa, A.P. Armazenamento de água em dois solos sob diferentes usos e manejos. Revista de Ciências Ambientais, v.10, n.2, p.55-65, 2016. https://doi. org/10.18316/1981-8858.16.31.

Davide, A.C.; Melo, L.A.; Teixeira, L.A.F.; Prado, N.J.S.; Fiorine, R.A.; Carvalho, R.P. Fatores que afetam a qualidade de mudas destinadas aos projetos de restauração de ecossistemas florestais. In: Davide, A.C.; Botelho, S.A. (Eds.). Fundamentos e métodos de restauração de ecossistemas florestais: 25 anos de experiência em matas ciliares. Lavras: UFLA, 2015. Cap. 5, p.181$274 p$.

Dickson, A.; Leaf, A.L.; Hosner, J.F. Quality appraisal of white spruce and white pine seedling stock in nurseries. Forestry Chronicle, v.36, n.1, p. 10-13, 1960. https://doi.org/10.5558/tfc36010-1.

Ferreira, E.B.; Cavalcanti, P.P.; Nogueira, D.A. ExpDes: Experimental Designs pacakge. R package version 1.1.2. 2013. https://cran.rproject.org/web/packages/ExpDes/ExpDes.pdf. 02 Ago. 2019.

Gomes Júnior, R.A.; Pina, A.J.A.; Gurgel, F.L.; Franzini, V.I.; Carvalho, 
E.A.; Veiga, A.S.; Bhering, L L.; Cunha, R.N.V. Sistema de produção de mudas em híbridos interespecíficos entre Caiaué e Dendê. Ciência Florestal, v.27, n.1, p.169-179, 2017. https://doi. org/10.5902/1980509826456.

Gonçalves, F.G.; Alexandre, R.S.; Silva, A.G.; Lemes, E.Q.; Rocha, A.P.; Ribeiro, M.P.A. Emergência e qualidade de mudas de Enterolobium contortisiliquum (Vell.) Morong (Fabaceae) em diferentes substratos. Revista Árvore, v.37, n.6, p.1125-1133, 2013. https://doi.org/10.1590/S0100-67622013000600014.

Gonzaga, L.M.; Silva, S.S.; Campos, S.A. Ferreira, R.P.; Campos, A.N.R.; Cunha, A.C.M.C.M. Evaluation of subtrates and AMF sporulation in the productions of seedlings of native forest species. Revista Árvore, v.40, n.2, p.245-254, 2016. https://doi. org/10.1590/0100-67622016000200007.

Instituto Nacional de Meteorologia - INMET. Clima. Diamantina 2017. http://www.inmet.gov.br/portal. 28 Jul. 2019.

Klein, J.; Rodrigues, J.D.; Kestring, D.; Rampim, L.; Aleixo, V.; Battistus, A.G. Desenvolvimento inicial de plântulas de Peltophorum dubium (Spreng.) Taub. sob protetores físicos com diferentes níveis de luminosidade. Nativa, v.5, n.2, p.92-100, 2017. https:// doi.org/10.5935/2318-7670.v05n02a03.

Kratka, P.C.; Correia, C.R.M.A. Crescimento inicial de aroeira do sertão (Myracrodruon urundeuva Allemão) em diferentes substratos. Revista Árvore, v.39, n.3, p.551-559, 2015. https:// doi.org/10.1590/0100-67622015000300016.

Labouriau, L.G. A germinação das sementes. Washington: Secretaria Geral da Organização dos Estados Americanos, 1983. 174p.

Lima, A.L.S.; Zanella, F.; Castro, L.D.M. Crescimento de Hymenaea courbaril L. var. stilbocarpa (Hayne) Lee et Lang. e Enterolobium contortisiliquum (Vell.) Morong (Leguminosae) sob diferentes níveis de sombreamento. Acta Amazonica, v.40, n.1, p.43-48, 2010. https://doi.org/10.1590/S0044-59672010000100006.

Maguire, J.D. Speed of germination and in selection and evaluation from seeding emergence and vigor. Crop Science, v.2, n.2, p.176177, 1962. https://doi.org/10.2135/cropsci1962.0011183X0002 00020033x.

Mendiburu, F. Statistical Procedures for Agricultural Research. Type Package "agricolae", 2016. https://cran.r-project.org/web/ packages/agricolae/index.html. 28 Jul. 2019.

Mercês, D.A.; Pinheiro, M.P.; Oliveira Filha, J.A.; França, S.; Gomes,
F.P.; Fiaschi, P.; Mielke, M.S. Sobrevivência de plântulas, características fotossintéticas e crescimento de Discocarpus pedicellatus (Phyllanthaceae). Rodriguésia, v.64, n.1, p.001-010, 2013. http://dx.doi.org/10.1590/S2175-78602013000100001.

Nery, F.C.; Prudente, D.O.; Alvarenga, A.A.; Paiva, R. Nery, M.C. Desenvolvimento de mudas de guanandi (Calophyllum brasiliensis Cambess.) sob diferentes condições de sombreamento. Revista Brasileira de Biociências, v.14, n.3, p.187-192, 2016. http://www. ufrgs.br/seerbio/ojs/index.php/rbb/article/view/3656. 02 Ago. 2019.

Oliveira, L.M.B. Sobrevivência e crescimento de mudas resgatadas em função do tempo de transplantio e níveis de sombreamento. Diamantina: Universidade Federal dos Vales do Jequitinhonha e Mucuri, 2014. 60p. Dissertação Mestrado. http://acervo.ufvjm. edu.br/jspui/handle/1/333. 06 Set. 2019.

Pimentel, L.D.; Bruckner, C.H.; Manfio, C.E.; Motoike, S.Y.; Matinez, H.E.P. Substrate, lime, phosphorus and topdress fertilization in Macaw Palm seedling production. Revista Árvore, v.40, n.2, p.235244, 2016. https://doi.org/10.1590/0100-67622016000200006.

Reis, S.M.; Marimon-Júnior, B.H.; Morandi, P.S.; Oliveira-Santos, C.; Oliveira, B.; Marimon, B.S. Desenvolvimento inicial e qualidade de mudas de Copaifera langsdorffii Desf. Sob diferentes níveis de sombreamento. Ciência Florestal, v.26, n.1, p.11-20, 2016. https://doi.org/10.5902/1980509821061.

Ribeiro, A.C.; Guimarães, P.T.G.; Alvarez, V.V.H. (Eds.). Recomendações para o uso de corretivos e fertilizantes em Minas Gerais - 5a aproximação. Viçosa: CFSEMG, 1999. p. 25-32.

Silva, J. M. Revisão histórica da diversidade vegetal da Zona da Mata Norte de Pernambuco com ênfase no município de Goiana. Revista Espaço Acadêmico, v.16, n.191, p. 12-26, 2017. http:// www.periodicos.uem.br/ojs/index.php/EspacoAcademico/ article/view/35815. 25 Ago. 2019.

Silva, W.M.; Lolis, S.F.; Viana, R.H.O. Composition ans structure of the gallery forest in the Taquaruçu Grand Sub-basin, Municipality of Palmas, Tocantins State. Acta Scientiarum. Biological Sciences, v.38, n.1, p.17-24, 2016. https://doi.org/10.4025/actascibiolsci. v38i1.28663.

Taiz, L., Zeiger, E. Fisiologia vegetal. 5.ed. Porto Alegre: Artmed, 2013. $918 p$. 